\title{
CCNB3 wt Allele
}

National Cancer Institute

\section{Source}

National Cancer Institute. CCNB3 wt Allele. NCI Thesaurus. Code C139673.

Human CCNB3 wild-type allele is located in the vicinity of Xp11.22 and is approximately $149 \mathrm{~kb}$ in length. This allele, which encodes $\mathrm{G} 2 /$ mitotic-specific cyclin-B3 protein, is involved in the progression of the cell cycle. A paracentric chromosomal inversion inv(X) (p11.4;p11.22) fuses this gene and the BCOR gene; this fusion is associated with bone sarcomas. 